\title{
Ultrastructural analysis of bovine oocytes from ovarian follicles with different diameters
}

\section{Análise ultra-estrutural de oócitos bovinos provenientes de folículos ovarianos com diferentes diâmetros}

\author{
Lívia Aires Lisboa ${ }^{*}$; Evelyn Rabelo Andrade²; Cesar Roberto Esper ${ }^{3}$; Marcelo \\ Marcondes Seneda ${ }^{4}$
}

\begin{abstract}
In vitro embryo production is an important technique for facilitating the reproduction of animals with high genetic merit. The greatest challenge for the reproducibility of this technique is the quality of the oocyte that is submitted for in vitro maturation. The aim of this work was to evaluate the ultrastructural characteristics of oocytes from follicles of different diameters using transmission electron microscopy. The animals were divided into 2 groups and were given a single i.m. injection of 250 IU FSH (Pluset, Serono, Italy). To synchronize the follicular growth, all follicles $>2 \mathrm{~mm}$ were aspirated during the estrous cycle, which was considered day zero (D0). Group $1(\mathrm{G} 1 ; \mathrm{n}=4)$ received FSH on day $1(\mathrm{D} 1)$, and the 2to 5 - $\mathrm{mm}$ follicles were aspirated on day $2(\mathrm{D} 2)$. The animals in group $2(\mathrm{G} 2 ; \mathrm{n}=5)$ received FSH on day 2 (D2), and their 10- to $15-\mathrm{mm}$ follicles were aspirated on day 5 (D5). After aspiration, the oocytes from both groups were fixed and prepared for ultrastructural analysis. The oocytes analyzed from both groups had similar ultrastructural characteristics. The presence and distribution of organelles in the cytoplasm of the oocytes did not differ between groups, suggesting that, in relation to the ultrastructural characteristics, oocytes from 2 to $5 \mathrm{~mm}$ and 10 to $15 \mathrm{~mm}$ follicles are similar.
\end{abstract}

Key words: Follicle size, OPU, electron microscopy

\section{Resumo}

A produção in vitro de embriões é uma técnica importante para facilitar a reprodução de animais com elevado mérito genético. O maior desafio para a reprodutibilidade desta técnica é a qualidade do oócito destinado à maturação in vitro. O objetivo deste trabalho foi avaliar as características ultra-estruturais de oócitos provenientes de folículos com diferentes diâmetros por microscopia eletrônica de transmissão. Os animais foram divididos em dois grupos e receberam uma única injeção im de 250 UI de FSH (Pluset, Serono, Itália). Para sincronizar o crescimento folicular, todos os folículos $>2 \mathrm{~mm}$ foram aspirados durante o ciclo estral, que foi considerado o dia zero (D0). O Grupo $1(\mathrm{G} 1, \mathrm{n}=4)$ recebeu FSH no dia 1 (D1), e os folículos de 2 a $5 \mathrm{~mm}$ foram aspirados no dia 2 (D2). Os animais do grupo 2 (G2, n =5) receberam FSH no dia 2 (D2), e os folículos de 10 a $15 \mathrm{~mm}$ foram aspirados no dia 5 (D5). Após a aspiração, os oócitos de ambos os grupos foram fixados e preparados para análise ultra-estrutural. Os oócitos analisados de ambos os grupos apresentaram características ultra-estruturais semelhantes. A presença e distribuição de organelas no citoplasma dos oócitos não diferiram entre os grupos, sugerindo

${ }^{1}$ Doutoranda na área de Reprodução Animal, Universidade Estadual de Londrina, UEL. Londrina, PR. E-mail: lisboavet@gmail. com

2 Pós-doutoranda na área de Reprodução Animal, UEL. Londrina, PR. E-mail: evelyn_andrade@yahoo.com

3 Prof. Dr. do Dept ${ }^{\circ}$ de Medicina Veterinária Preventiva e Reprodução Animal da Universidade Estadual Paulista, UNESP, São Paulo, SP. E-mail: cresper@fcav.unesp.br

${ }^{4}$ Prof. Dr. do Dept ${ }^{\circ}$ de Clínicas Veterinárias, Centro de Ciências Agrárias, UEL, Londrina, PR. E-mail: mseneda@uel.br

* Autor para correspondência 
que, em relação às características ultra-estruturais, oócitos oriundos de folículos de 2-5 mm e 10-15 mm são similares.

Palavras-chave: Tamanho do folículo, OPU, microscopia eletrônica

\section{Introduction}

In vitro embryo production (IVP) is a useful tool for facilitating the reproduction of animals with improved genotypes (CAMARGO et al., 2010) and is used for commercial and research purposes. The embryos are produced by in vitro maturation and fertilization of immature oocytes recovered by ovum pick up (OPU) from a live donor. Although researches have optimized IVP, there are still steps that can be improved in order to minimize the variability of the results. One of these variable steps is blastocysts production. In cattle, oocytes collected from 3- to 8-mm antral follicles can be rescued by in vitro embryo production techniques. However, many of these oocytes go through maturation and still fail to produce viable embryos (LEQUARRE et al., 2005).

Some studies have shown that the quality of the oocyte is the main factor affecting blastocyst yield, and that given a good quality oocyte, culture conditions are secondary (RIZOS et al., 2002; 2003). Oocyte quality can be influenced by several factors such as the donor animals' physiological and reproductive status, follicle size, oocyte diameter and characteristics of cumulus cell (LONERGAN et al., 1994; LEIBFRIED-RUTLEDGE, 1999; ARMSTRONG, 2001; NANDI et al., 2002). The follicle size has been used as a non-invasive criteria to select the most competent oocytes in cattle (LEQUARRE et al., 2005), sheep (COGNIÉ et al., 1998) and goats (CROZET; AHMEDALI; DUBOS, 1995). Although some authors have observed a positive relationship between the follicle diameter and oocyte competence (LONERGAN et al., 1994; LEQUARRE et al., 2005), others studies have found little or no relationship between these parameters (PAVLOK; LUCAS-HAHN; NIEMANN, 1992; FAIR et al., 1997; SENEDA et al., 2001). Shirazi and Sadeghi
(2007) demonstrated that the quality of oocytes from follicles of different sizes may be the primary source of variation in the in vitro maturation process.

Considering the importance of oocyte quality and that ultrastructural analysis can result in a better understanding of oocyte biology and improve in vitro oocyte development (KAFI et al., 2005), the aim of this study was to evaluate, by transmission electron microscopy, the distribution of organelles in the cytoplasm of oocytes that were obtained from follicles with different diameters and to establish an appropriate follicular diameter for follicular aspiration.

\section{Materials and Methods}

\section{Animals}

Non-pregnant, non-lactating, healthy and cycling Blond d'Aquitane and Caracu cross breeding cows ( $\mathrm{n}=9$, around 7 years of age) were kept exclusively on pasture plus mineral salt and water ad libitum. The regularity of the estrous cycle was evaluated by ultrasound examination of ovarian activity during the 60 days before the experiment. The animals were located on a farm in Uraí city in the state of Paraná, Brazil at latitude $23^{\circ} 11^{\prime} 52^{\prime \prime}$ south, longitude $50^{\circ} 47^{\prime} 45^{\prime \prime}$ west and an altitude of 435 meters.

\section{Ultrasonographic and OPU equipment}

Ultrasonographic procedures were performed using an ultrasound scanner (Scanner 200 Vet, Pie Medical, The Netherlands) with a $7.5 \mathrm{MHz}$ sector transducer fitted into the transvaginal device (Pie Medical, The Netherlands). Follicular aspiration was performed with disposable hypodermic 
needles that were $50 \mathrm{~mm} \mathrm{X} 19$ gauge (Terumo, Brazil) and silicon tubing $(0.8 \mathrm{~m} ; 2 \mathrm{~mm}$ i.d.). A vacuum pressure of 65 to $70 \mathrm{~mm} \mathrm{Hg}(15 \mathrm{~mL}$ of water/min) was maintained with a vacuum pump (Rocket Medical, England) as performed by Bols et al. (1997). The flushing medium consisted of phosphate buffered saline (PBS; Nutricell, Brazil) supplemented with $10 \%$ fetal calf serum (Nutricell, Brazil) and $17 \mathrm{IU} / \mathrm{ml}$ heparin (Bergamo, Brazil).

\section{Donor preparation}

Each cow received epidural anesthesia $(7 \mathrm{~mL}$ of $2 \%$ lidocaine) and the rectum was emptied, the perineum was cleaned and $70 \%$ ethanol was used for antisepsis. The transducer was completely introduced into the vagina, and through rectal manipulation, the ovaries were positioned on the ultrasound transducer to obtain a clear image on the ultrasonographic monitor.

\section{Follicular aspiration}

To synchronize follicular growth, all follicles > $2 \mathrm{~mm}$ were aspirated during a random moment of the estrous cycle, which was considered day zero (D0). The animals were divided into 2 groups. Group one received a single i.m. injection of 250 IU FSH (Pluset, Serono, Italy) $(\mathrm{G} 1 ; \mathrm{n}=4)$ on day 1 (D1), and then the follicles that were 2 to $5 \mathrm{~mm}$ in diameter were aspirated on day 2 (D2). The animals in group $2(\mathrm{G} 2 ; \mathrm{n}=5)$ received $\mathrm{FSH}$ on day 2 (D2), and the follicles with a diameter of 10 to 15 $\mathrm{mm}$ were aspirated on day 5 (D5).

After measurement, follicular aspiration was performed in both ovaries. All procedures were performed by the same operator.

\section{Analysis of oocytes with transmission electron microscopy}

After aspiration, 25 oocytes from $\mathrm{G} 1$ and 32 oocytes from G2 were fixed and prepared for analysis using light and electron microscopy according to the technique described by De Bem (1982). The oocytes were fixed in $1 \%$ glutaraldehyde in $0.15 \mathrm{M}$ sodium cacodylate buffer ( $\mathrm{pH}$ 7.6) for 1 hour, then washed in the same buffer, and post-fixed in 1\% osmium tetroxide for 3 hours at $4^{\circ} \mathrm{C}$. Subsequently, oocytes were washed in bidistilled water, dehydrated in increasing series of ethanol and was realized the inclusion according to the technique described by Esper and Barbosa (1991). Samples were embedded in Epan-812 and cut into semi-thin sections $(0.5 \mu \mathrm{m})$ that were stained with toluidine blue and analyzed with a light microscope (Zeiss, Germany). Thin sections (60-70 nm) were obtained using a diamond razor mounted in copper grating that was contrasted with uranyl acetate and lead citrate. The samples were then examined with a transmission electron microscope (Jeol, JEM-100 C, Japan).

The results were not statistically analyzed because the experiments are qualitative.

\section{Results}

All of the oocytes that were analyzed were surrounded by zona pellucida and had an average thickness of $15 \mu \mathrm{m}$. The external structure was less compact than the internal one. The cytoplasm did not differ between the two groups; they were electron-dense and homogeneous. Mitochondria, vesicles, Golgi complex and lipid drops were found in the cytoplasm, whereas ribosomes were not observed, which indicates that during this stage there is no significant protein synthesis. The dissection of the samples did not reach the nuclear area; therefore, the components, such as the nucleus and chromatin, were not observed. Microvilli in the perivitelline space were seen in all of the oocytes in both groups (Figure 1A/B). Group 1 oocytes had cellular processes from the granulosa cells that crossed the zona pellucida, went through the perivitelline space and eventually reached the plasmalemma. 
Figure 1A. Oocytes from small diameter follicles (group 1). Perivitelline space (PS), microvilli (MV), vesicles (V), zona pellucida (ZP).

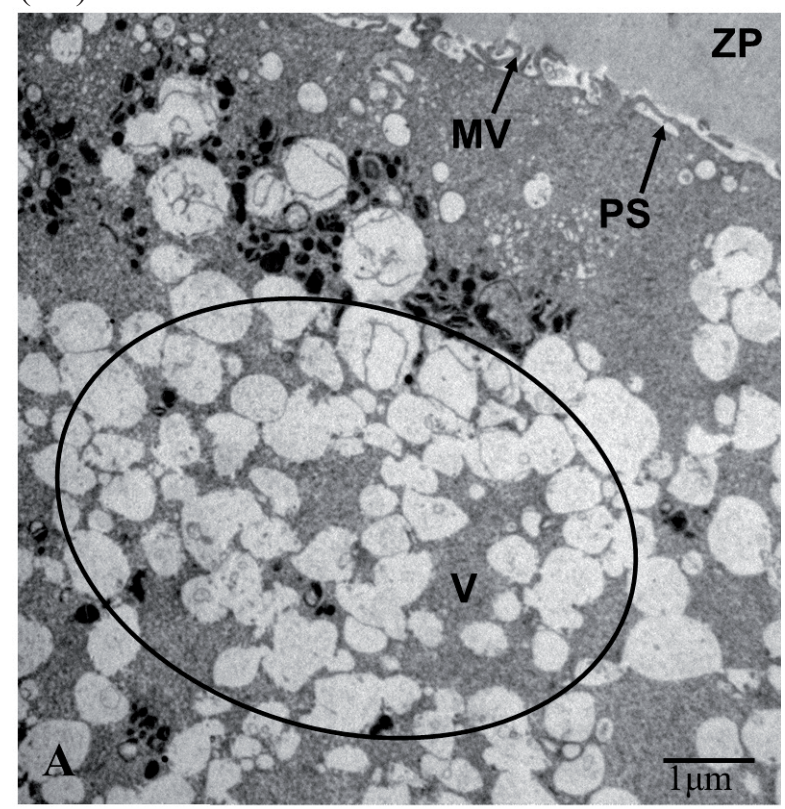

Figure 1B. Oocytes from large follicles (group 2). Perivitelline space (PS), microvilli (MV), vesicles (V), zona pellucida (ZP).

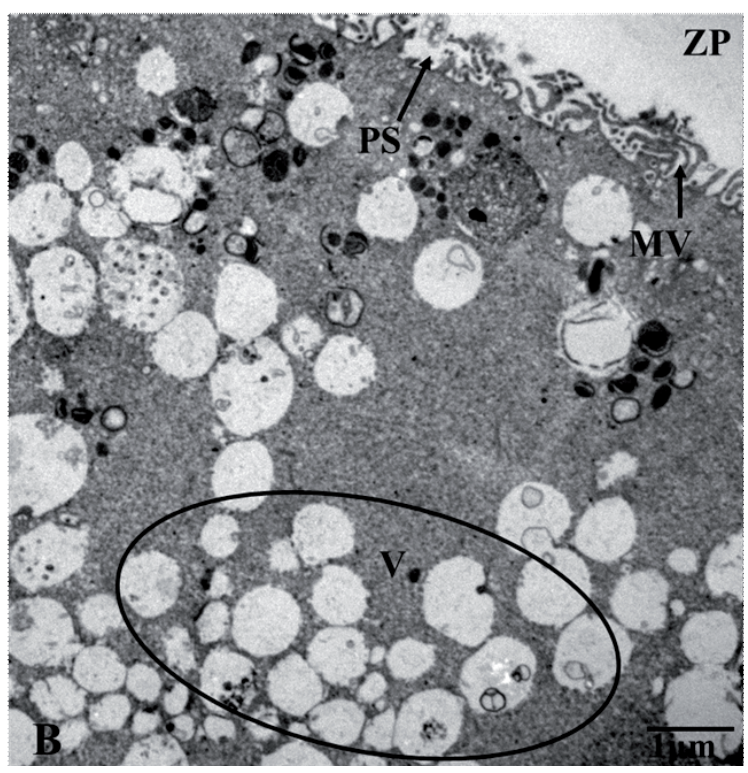

In all of the oocytes that were examined, we found vesicles distributed throughout the cytoplasm (Figure 1A/B). The vesicles were morphologically similar to multivesicle bodies and varied in shape and size ( 0.1 to $0.3 \mu \mathrm{m}$ of diameter); most had electron-dense contents. Additionally, the cortical granules were in clusters, with an average of 25 to 100 units in each cluster (Figure 2A/B).

In both groups, the shape of the mitochondria was 
variable: polygonal, spherical or oval. Additionally, they varied in the number and arrangement of the matrix and cristae (Figure 2A/B). The mitochondria were grouped in small clusters, with large numbers of immature and hooded forms, as described by Senger and Saacke (1970) and Fleming and Saacke
(1972).

Crystalloid inclusions of different sizes, originally described by Enders (1965), were also found in the cytoplasm of the oocytes from both groups. Their function is currently unknown.

Figure 2A. Oocytes from group 1. Cluster of cortical granules (CG), mitochondria (M), zona pellucida (ZP).

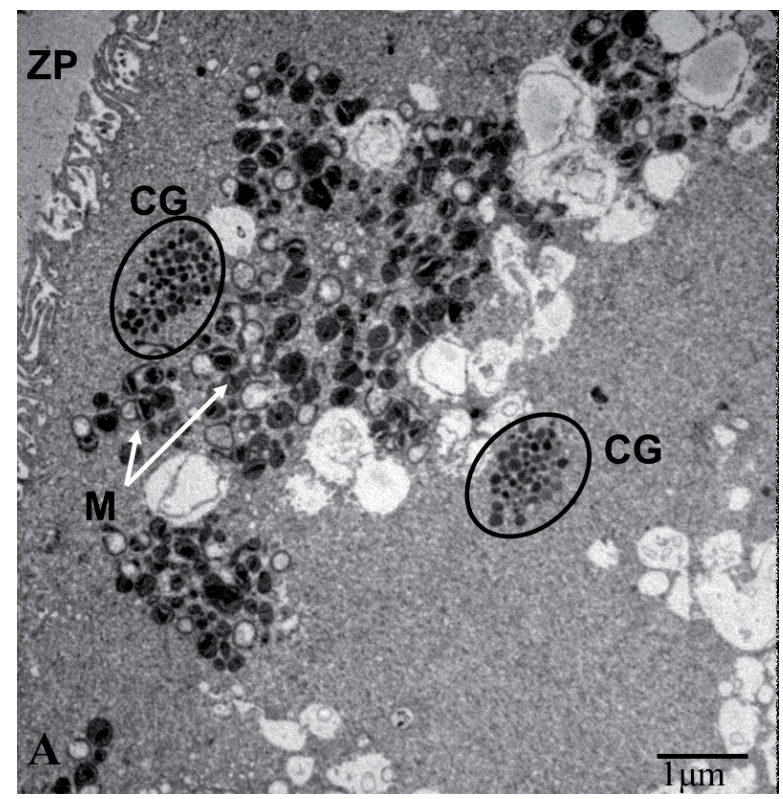

Figure 2B. Oocytes from group 2. Cluster of cortical granules (CG), mitochondria (M), zona pellucida (ZP).

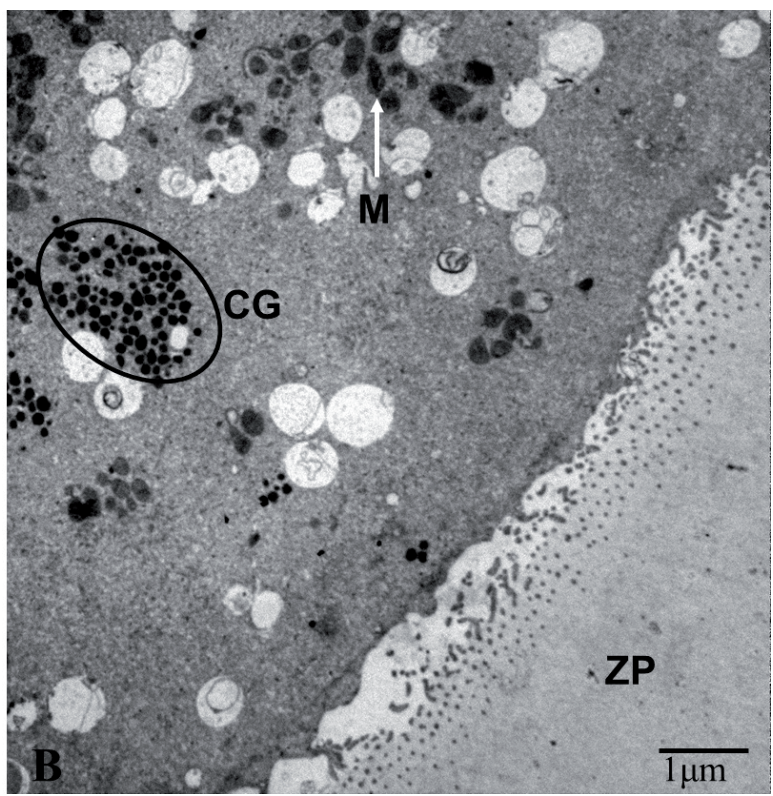




\section{Discussion}

The diameter of the oocyte can reach up to $3 \mathrm{~mm}$ while in follicles that are 3 to $10 \mathrm{~mm}$. The oocyte diameter does not change until it resumes its growth, by increasing transcriptional activity, in follicles that are between 10 and $15 \mathrm{~mm}$ (MERTON et al., 2003). In this study, we analyzed oocytes from follicles with different diameters $(2-5 \mathrm{~mm}$ and $10-15 \mathrm{~mm}$ ). Despite the previously mentioned differences regarding oocyte growth in relation to the size of the follicle, we did not find any ultrastructural changes between the two groups of oocytes that were aspirated.

The zona pellucida was normal in both groups; it was completely formed, attached to the ooplasm and did not show signs of degeneration, such as shrinkage or disruption. However, a few oocytes from group 1 had cytoplasmic projections from granulosa cells crossing the zona pellucida, which was not observed in group 2. Fleming and Saacke (1972) found that oocytes increase activity and reduce their dependence on the granulosa cells when meiosis resumes. Therefore, the oocytes in group 2 may have been in a more advanced stage of development than those in group 1. Between the zona pellucida and the oocyte, a perivitelline space containing microvilli was found in all oocytes analyzed, which is characteristic of oocytes in the antral follicle (FAIR et al., 1997) and suggests that the oocytes were growing normally, even in the follicles with smaller diameters.

The oolema of both groups contained many vesicles that were widely distributed. Rüsse (1983) described a possible role of these vesicles as nutrient reserves. However, Fair et al. (1997) proposed that these vesicles participate in the formation of cortical granules because of the close proximity of these two organelles. The same was observed in this study. Most of vesicles had no apparent content. However, an electron-dense content was observed in a few pictures and may be related secretory activity. This dual presentation of the vesicles has made it difficult to determine their physiological activity, but regardless of their function, no differences were observed between the groups studied.

The cortical granules are secretory vesicles that are produced during oogenesis (ZHANG et al., 2010). They are unique to oocytes, and their composition includes a diverse population of proteins, structural molecules, enzymes, and glycosaminoglycans (FERREIRA et al, 2009). Cortical granules have been related to the proper growth of the oocyte (FAIR et al., 1997). The abundance of these structures in the oocytes of both groups suggests that the female gamete is developing correctly. As for the location of these granules, our findings are consistent with the description of immature oocytes, in which the cortical granules are grouped in clusters and distributed throughout the ooplasm (DIEZ et al., 2005). The reduction and migration of cortical granules to peripheral area of the ooplasm and the forming of a line along the oolema is considered an essential component of normal oocyte maturation (FAIR; HYTTEL; GREVE, 1995). During fertilization, exocytosis of these cortical granules prevents polyspermy.

Oocytes from animals that have received gonadotropin stimulation are rich in pleomorphic mitochondria(ASSEY; HYTTEL;KANUYA, 1994). Pleomorphic mitochondria were widely observed in oocytes from both groups, which suggests that the oocytes were effectively sensitized by the gonadotrophic stimulus given by FSH injection. Mitochondria are the most abundant organelles in mammalian oocytes and play an important role in oocyte metabolism. They produce energy for maturation and fertilization (SHOUBRIDGE AND WAI, 2007). The predominance of "hooded" mitochondria is correlated with the proximity to meiotic maturation (FAIR; HYTTEL; GREVE, 1995). Despite the presence of this kind of mitochondria, which was not the most abundant type, suggests that the oocytes of both groups were quiescent. As for location, the mitochondria were distributed throughout the cytoplasm but 
were mainly in the periphery of oolema, which is consistent with immature oocytes. A more peripheral distribution is observed in oocytes before the surge of luteinizing hormone. During the maturation process, the mitochondria move to a central position (HYTTEL et al., 1997).

All of the oocytes that were analyzed had characteristics of immature oocytes, including numerous mitochondria scattered throughout the cytoplasm, a perivitelline space and microvilli that were not fully developed, and many vesicles and clusters of cortical granules throughout the ooplasm (DIEZ et al., 2005; FERNANDES et al., 2006).

The results presented in this paper make it possible to conclude that, after the administration of exogenous gonadotropins, oocytes from small antral follicles are ultrastructurally similar to the oocytes from large follicles.

\section{Acknowledgments}

The authors thank FCAVJ and UEL for laboratory support and the Santa Gabriela Farm.

\section{References}

ARMSTRONG, D. T. Effects of maternal age on oocyte developmental competence. Theriogenology, Philadelphia, USA, v. 55, n. 6, p. 1303-1322, 2001.

ASSEY, R. J.; HYTTEL, P.; KANUYA, N. Oocyte strutcture in dominant and subordinate follicles in zebu cattle (Bos indicus). Anat Embryol, Berlin, v. 190, n. 5, p. 461-468, 1994.

BOLS, P. E. J.; YSEBAERT, M. T.; VAN SOOM, A.; KRUIF, A. Effects of needle tip bevel and aspiration procedure on the morphology and developmental capacity of bovine compact cumulus oocyte complex. Theriogenology, Philadelphia, USA, v. 47, n. 6, p. 12211236, 1997.

CAMARGO, L. S. A.; FREITAS, C.; FERREIRA DE SA, W.; FERREIRA, A. M.; SERAPIAO, R. V.; VIANA, J. H. M. Gestation length, birth weight and offspring gender ratio of in vitro-produced Gyr (Bos indicus) cattle embryos. Anim Reprod Sci., Amsterdam, v. 120, n. 4, p. 10-15, 2010.
COGNIÉ, Y.; BENOIT, F.; POULIN, N.; KHATIR, H.; DRIANCOURT, M. Effect of follicle size and of the FecB Booroola gene on oocyte function in sheep. $J$ Reprod Fertil, Southampton, UK, v. 112, n. 2, p. 379386, 1998.

CROZET, N.; AHMED-ALI, M.; DUBOS, M. P. Developmental competence of goat oocytes from follicles of different size categories following maturation, fertilization and culture in vitro. J Reprod Fertil, Southampton, UK, v. 103, n. 2, p. 293-298, 1995.

$\mathrm{DE}$ BEM, A. R. Effect de la superovulation et de la congelation sur le blastocyste de vache. Etude ultrastructural. 1982. Tese (Docteur du 3 ème cycle) L'Universite Pierre \& Marie Curie (Paris VI), Paris.

DIEZ, C.; DUQUE, P.; GÓMEZ, H.; HIDALGO, C. O.; TAMARGO, C.; RODRÍGUEZ, A.; FERNÁNDEZ, L.; DE LA VARGA, S.; FERNÁNDEZ, A.; FACAL, N.; CARBAJO, M. Bovine oocyte vitrification before or after meiotic arrest: effects on ultrastructure and developmental ability. Theriogenology, Philadelphia, USA, v. 64, p. 317-333, 2005.

ENDERS, A. C. A comparative study of the fine structure of the trophoblast in several hemochorial placentas. Amer JAnat, New York, v. 116, p. 29-67, 1965.

ESPER, C. R.; BARBOSA， J. C. Ultraestrutura comparativa de embriões bovinos. In: CONGRESSO BRASILEIRO DE REPRODUÇÃO ANIMAL, 2., 1991, Belo Horizonte. Anais... Belo Horizonte: CBRA., 1991. p. 295.

FAIR, T.; HULSHOF, S. C. J.; HYTTEL, P.; GREVE, T. Oocyte ultrastrutcture in bovine primordial to early tertiary follicles. Anat Embryol, Berlin, v. 195, n.4, p. 327-336, 1997.

FAIR, T.; HYTTEL, P.; GREVE, T. Bovine oocytes diameter in relation to maturational competence and transcriptional activity. Mol Reprod Dev, Malden, USA, v. 42, n. 4, p. 437-442, 1995.

FERNANDES, C. B.; PERES, K. R.; ALVARENGA, M. A.; LANDIM-ALVARENGA, F. C. The use of tranmission electron microscopy and oocyte transfer to evaluate in vitro maturation of equine oocytes in different culture conditions. J Equine Vet Sci, Kentucky, v. 26, n. 4, p. 159-167, 2006.

FERREIRA, E. E. M.; VIREQUE, A. A.; ADONA, P. R.; MEIRELLES, F. V.; FERRIANI, R. R.; NAVARRO, P. A. A. S. Cytoplasmic maturation of bovine oocyte: structural and biochemical modifications and acquisition of development competence. Theriogenology, Philadelphia, USA, v. 71, n. 5, p. 836-848, 2009.

FLEMING, W. N.; SAACKE, R. G. Fine structure of 
the bovine oocyte from the mature Graafian follicle. $J$ Reprod Fertil, Southampton, UK, v. 29, n. 2, p. 203-213, 1972.

HYTTEL, P.; FAIR, T.; CALLENSEN, H.; GREVE, T. Oocyte growth, capacitation and final maturation in cattle. Theriogenology, Philadelphia, USA, v. 47, n. 1, p. 23-32, 1997.

KAFI, M.; MESBAH, F.; NILI, H.; KHALILI, N. Chronological and ultrastructural changes in camel (Camelus dromedarius) oocytes during in vitro maturation. Theriogenology, Philadelphia, USA, v. 63, n. 9, p. 2458-2470, 2005.

LEIBFRIED-RUTLEDGE, M. L. Factors determining competence of in vitro produced cattle embryos. Theriogenology, Philadelphia, USA, v. 51, n. 2, p. 473485, 1999.

LEQUARRE, A. S.; VIGNERON, C.; RIBAUCOUR, F.; HOLM, P.; DONNAY. I.; DALBIES-TRAN, R.; CALLESEN, H.; MERMILLOD, P. Influence of antral follicle size on oocyte characteristics and embryo development in the bovine. Theriogenology, Philadelphia, USA, v. 63, n. 3, p. 841-859, 2005.

LONERGAN, P.; MONAGHAN, P.; RIZOS, D.; BOLAND, M. P.; GORDON, I. Effect of follicle size on bovine oocyte quality and developmental competence following maturation, fertilization, and culture in vitro. Mol Reprod Dev, Malden, USA, v. 37, n. 1, p. 48-53, 1994.

MERTON, J. S.; DE ROOS, A. P. W.; MULLAART, E.; DE RUIGH, L.; KAAL, L.; VOS, P. L. A. M.; DIELEMAN, S. J. Factors affecting oocyte quality and quantity in commercial application of embryou technologies in the cattle breeding industry. Theriogenology, Philadelphia, USA, v. 59, n. 2, p. 651674, 2003.

NANDI, S.; RAGHU, H. M.; RAVINDRANATHA, B. M.; CHAUHAN, M. S. Production of buffalo (Bubalus bubalis) embryos in vitro: Premises and Promises. Reprod Dom Anim, Linköping, Sweden, v. 37, n. 2, p. 65-74, 2002.

PAVLOK, A.; LUCAS-HAHN, A.; NIEMANN, H. Fertilization and developmental competence of bovine oocytes derived from different categories of antral follicles. Mol Reprod Dev, Malden, USA, v. 31, n. 1, p. 63-67, 1992.

RIZOS, D.; GUTIERREZ-ADAN, A.; PEREZGARNELO, S.; DE LA FUENTE, J.; BOLAND, M. P.; LONERGAN, P. Bovine embryo culture in the presence or absence of serum: Implications for blastocyst development, cryotolerance, and messenger RNA expression. Biol Reprod., Madison, USA, v. 68, n. 1, p. 236-243, 2003.

RIZOS, D.; WARD, F.; DUFFY, P.; BOLAND, M. P.; LONERGAN, P. Consequences of bovine oocyte maturation, fertilization or early embryo development in vitro versus in vivo: implications for blatocyst yield and blastocyst quality. Mol Reprod Dev, Malden, USA, v. 61, n. 2, p. 234-248, 2002.

RÜSSE, I. Oogenesis in cattle and sheep. Bibl. Anat., v. 24, p. 77-92, 1983.

SENEDA, M. M.; ESPER, C. R.; GARCIA, J. M.; VANTINI, R.; OLIVEIRA, J. A. Relationship between follicle size and ultrasound-guided transvaginal oocyte recovery. Anim Reprod Sci, Amsterdam, v. 67, n. 2, p. 37-43, 2001.

SENGER, P. L.; SAACKE, R. G. Unusual mitochondrias of the bovine oocyte. Journal of Cell Biology, New York, v. 46, n. 2, p. 405-408, 1970.

SHIRAZI, A.; SADEGHI, N. The effect of ovine oocyte diameter on nuclear maturation. Small Ruminant Res, Thessaloniki, Greece, v. 69, n. 3, p. 103-107, 2007.

SHOUBRIDGE, E. A.; WAI, T. Mitochondrial DNA and the mammalian oocyte. Curr Top Dev Biol, PA, U.S.A, v. 77, p. 87-111, 2007.

ZHANG, T.-T.; JIANG, Y.-Q.; ZHOU, H.; YANG, W. X. Ultrastructural observation on genesis and morphology of cortical granules in Macrobrachium nipponense (Crustace, Caridea). Micron, Sydney, Austrália, v. 41, n. 1, p. 59-64, 2010. 